УДК 343.163

DOI https://doi.org/10.32849/2663-5313/2020.12.50

\title{
Таїсія Боднарук,
}

студентка

Інституту прокуратури та кримінальної юстиціі

Начіонального юридичного університету імені Ярослава Мудрого

Андрій Лапкін,

канд. юрид. наук,

доцент кафедри судоустрою та прокурорської діяльності

Начіонального юридичного університету імені Ярослава Мудрого

\section{ОСНОВНІ НАПРЯМИ РЕФОРМУВАННЯ ІНСТИТУТУ ПРОКУРАТУРИ НА СУЧАСНОМУ ЕТАПI}

У статті досліджується питання основних напрямів роботи прокуратури на сучасному етапі, з моменту прийняття оновленого Закону України «Про прокуратуру», проведення конституційної реформи щодо правосуддя та внесення суттєвих змін до вищезазначеного закону у 2019 роиі. Наголошується на непослідовності та неоднорідності реформи, що дає підстави деяким ученим та правникам стверджувати, що одночасно і здійснюється одна реформа прокуратури, і розпочинається наступна, без завершення попередньої.

Визначено, що впродовж періоду незалежності належним чином не визначено мету, завдання та функиії прокуратури. Мета є надто розмитою, завдання на законодавчому рівні не закріплені, а функиії по-різному відображені у Конституиії України та профільному законодавстві.

Крім того, прокуратура перевантажена надмірною кількістю функцій, що негативно відображається на ефективності ї̈ роботи.

Виникають також труднощі у здійсненні прощедури добору кандидатів на посади прокурорів, оскільки детально не визначено та нормативно не закріплено поняття вищої юридичної освіти та стажу роботи в галузі права. Постає питання про можливість визнання посади такою, що відповідає вимогам стажу у галузі права після отримання диплома спещіаліста чи магістра, якщо особа виконувала трудову функиію за вказаною посадою і до отримання такого диплому. Вказана невизначеність призводить до впливу суб'єктивного фактору на добір кандидатів.

Відзначено позитивні зміни у законодавстві щодо фінансування прокуратури, а саме скасування обмеження розміру заробітних плат прокурорів відповідно до обсягу державного і місиевих бюджетів, що виключило ризик залежності прокуратури від дискрещійних повноважень Кабінету Міністрів Украйни. Також зазначено, що таке скасування було зроблено з неточністю у мотивуванні, що в майбутньому може призвести до обов'язку передбачення розмірів заробітних плат нотаріату, органів досудового розслідування, органів і установ виконання покарань виключно у законодавчих актах. Зроблено висновки щодо повноти і послідовного проведення реформи прокуратури на сучасному етапі.

Ключові слова: реформування прокуратури, мета прокуратури, завдання прокуратури, функції прокуратури, фінансування прокуратури.

Постановка проблеми. Упродовж усього періоду незалежності інститут прокуратури перебуває у стані реформування. Процес реформування характеризується безсистемністю та непослідовністю. Як слушно зазначив О. О. Первомайський, суспільству слід очікувати або продовження та завершення вже розпочатої реформи прокуратури, або початку нової реформи [1]. 3 огляду на постійні зміни в інституті прокуратури необхідно визначитися з основними напрямами його реформування на сучасному етапі.
Метою статті $є$ визначення основних напрямів реформування інституту прокуратури на сучасному етапі.

Аналіз останніх досліджень та публікацій. Питання реформування інституту прокуратури на сучасному етапі досліджувалося у роботах А. В. Лапкіна, Ю. А. Чаплинської, Л. В. Омельчука, А. В. Бабінської.

Виклад основного матеріалу. У процесі здійснення численних спроб реформування прокуратури так чи інакше змінювалося цільове і функціональне призначення 
даного інституту. 3 огляду на це, доцільно насамперед зупинитися на визначенні мети, завдань та функцій прокуратури в умовах сьогодення.

Зазначимо, що деякі тлумачні словники ототожнюють категорії «мета» і «завдання», визначаючи їх як наперед визначений, запланований обсяг роботи, те, що хочуть здійснити / намагаються досягти [2].

Мета є найбільш загальною категорією, що визначає основні напрями, яких прагне прокуратура, для чого вона створена і діє. Як зазначає А. В. Лапкін, «мета має ідеальний характер, слугує дороговказом для функціонування прокуратури в цілому та виконання покладених на них обов'язків окремим прокурором, однак не може бути повністю реалізована. Отже, мета прокуратури є її надзавданням» [3]. Таким чином, мету можна визначити як певну цінність, на основі якої формуються завдання та функції прокуратури.

Завдання є вужчим поняттям, ніж мета, мають прикладний характер і підлягають більш детальній конкретизації. Певною мірою вони виступають засобом реалізації мети прокуратури.

Поняття функції також пов’язане з метою та завданнями, оскільки за своєю суттю функції є основними напрямами діяльності прокуратури, спрямовані на досягнення мети і виконання завдань, виражають іï сутність і призначення, обмежуються певною предметною сферою і передбачають особливі форми, методи і тактику здійснення.

Перейдемо до відображення мети, завдань та функцій прокуратури у законодавстві. Мета прокуратури передбачена у ст. 1 Закону України «Про прокуратуру» і визначається як захист прав і свобод людини, загальних інтересів суспільства та держави [4]. Таке формулювання мети є занадто широким i, на наш погляд, не сприяє ефективності роботи цього інституту [3].

На відміну від мети, завдання прокуратури взагалі не передбачені законодавством. Як наслідок, надто широкій меті відповідають вузько сформульовані функції, які не можуть повною мірою забезпечувати виконання мети. Оскільки завдання прокуратури не визначено, виникає питання щодо правильності визначення функцій прокуратури, які, як видається, не можуть забезпечити виконання мети у повному обсязі.

Доцільно зауважити, що до законодавчого закріплення функцій після проведення ряду реформ також виникає багато запитань.

Так, статтею 131-1 Конституції України закріплено такі функції:

1) підтримання публічного обвинувачення в суді;
2) організацію і процесуальне керівництво досудовим розслідуванням, вирішення відповідно до закону інших питань під час кримінального провадження, нагляд за негласними та іншими слідчими і розшуковими діями органів правопорядку;

3) представництво інтересів держави в суді у виключних випадках і в порядку, що визначені законом [5].

Крім того, пунктом 9 Перехідних положень Конституції передбачається, що прокуратура продовжує виконувати відповідно до чинних законів функцію досудового розслідування до початку функціонування органів, яким законом будуть передані відповідні функції, а також функцію нагляду за додержанням законів під час виконання судових рішень у кримінальних справах, під час застосування інших заходів примусового характеру, пов'язаних з обмеженням особистої свободи громадян, - до набрання чинності законом про створення подвійної системи регулярних пенітенціарних інспекцій [5].

Втім, у профільному законі залишився попередній перелік функцій прокуратури: підтримання державного обвинувачення в суді; представництво інтересів громадянина або держави в суді у випадках, визначених цим Законом та главою 12 розділу III Цивільного процесуального кодексу України; нагляд за додержанням законів органами, що провадять оперативно-розшукову діяльність, дізнання, досудове слідство; нагляд за додержанням законів при виконанні судових рішень у кримінальних справах, а також при застосуванні інших заходів примусового характеру, пов'язаних з обмеженням особистої свободи громадян. Залишається незрозумілою позиція законодавця, який, вносячи зміни до Конституції, не продублював ті самі положення у профільному законі, тим більше, що частиною 2 статті 131-1 Конституції передбачається, що організація та порядок діяльності прокуратури визначаються законом. Закон «Про прокуратуру» покликаний конкретизувати і доповнювати положення Конституції, але на сучасному етапі він суперечить положенням Основного Закону.

Перевантаження інституту прокуратури надмірною кількістю функцій також не видається доцільним, оскільки неминуче вестиме до зниження ефективності роботи органу.

Так, на час здійснення конституційної реформи щодо правосуддя на прокуратуру було покладено 5 функцій, різних за своїм спрямуванням. У 2019 році прокуратура зі створенням і початком функціонування Державного бюро розслідувань зрештою втра- 
тила повноваження проводити досудове розслідування, у зв'язку з чим усі незавершені розслідування передано відповідно до кваліфікації до Державного бюро розслідувань, Національного антикорупційного бюро України, Служби безпеки України [6]. Припинення здійснення функції досудового розслідування $€$ позитивною зміною у діяльності прокуратури, оскільки це суттєво зменшує навантаження органу і надає можливість з більшою ефективністю здійснювати інші, більш притаманні органам прокуратури функції.

Тим не менше, оскільки досі не створена подвійна система регулярних пенітенціарних інспекцій, за прокуратурою натепер залишається функція нагляду за додержанням законів під час виконання судових рішень у кримінальних справах, під час застосування інших заходів примусового характеру, пов'язаних з обмеженням особистої свободи громадян. Доцільність здійснення такої функції викликає дискусії. Одні правники вважають, що прокуратура повинна здійснювати нагляд за всім, що відбувається у місцях позбавлення волі, за законністю утримання осіб тощо. Проте опоненти стверджують, що в такій тезі закладений внутрішній конфлікт, оскільки виходить, що прокуратура, яка забезпечила перебування людини в місцях позбавлення волі, потім наглядає за дотриманням іï прав протягом відбування покарання [9]. Погодимося 3 думкою І. Б. Каліушко, що «існують ефективніші механізми нагляду за додержанням прав ув'язнених, наприклад розмежування адміністрації та охорони в пенітенціарних закладах, підпорядкування охорони органам внутрішніх справ» [7].

Вбачається, що функції прокуратури, закріплені у статті 131-1 Конституції, так чи інакше пов'язані з кримінальним провадженням. Отже, мету прокуратури доцільно узгодити з метою кримінального процесу. На наш погляд, слід уточнити, що прокуратура здійснює захист прав і свобод людини, інтересів суспільства та держави від кримінальних правопорушень, а також охороняє та забезпечує дотримання прав, свобод і інтересів учасників кримінального провадження.

3 огляду на уточнену мету, видається прийнятним підхід М. М. Бурбики щодо визначення таких завдань прокуратури: виявлення та усунення негативних соціальних процесів і явищ, що породжують злочинність або сприяють їй; виявлення, припинення, розслідування злочинів; притягнення винних до відповідальності; відшкодування шкоди фізичним та юридичним особам, державі [8].

Таким чином, на сучасному етапі мета, завдання і функції прокуратури характери- зуються певною невизначеністю у формулюваннях, а також суперечністю нормативних положень Конституції та профільного закону.

На відміну від мети, завдань та функцій, законодавчі зміни безпосередньо торкнулися вимог до кандидатів та процедури зайняття посади прокурора. Так, позитивним моментом € повернення вимоги щодо вищої освіти для зайняття посади Генерального прокурора. Проте у законі достатньою мірою не деталізовані поняття ані вищої юридичної освіти, ані стажу роботи в галузі права. Так, встановлено, що вищою юридичною освітою є освіта, здобута в Україні (або на території колишнього СРСР до 1 грудня 1991 року) за освітньо-кваліфікаційним рівнем спеціаліста або магістра, а також вища юридична освіта за відповідним освітньо-кваліфікаційним рівнем, здобута в іноземних державах та визнана в Україні в установленому законом порядку [4]. Однак поняття власне юридичної освіти у законі не наведене, що може призвести до суб'єктивного підходу у визначенні тієї чи іншої спеціальності як юридичної.

Те саме стосується поняття стажу роботи в галузі права. Законом це поняття визначається як стаж роботи особи за спеціальністю після здобуття нею вищої юридичної освіти за освітньо-кваліфікаційним рівнем спеціаліста або магістра [4]. Рішенням Кваліфікаційно-дисциплінарної комісії прокурорів від 07 лютого 2018 року № 30 дк-18 закріплено Перелік посад, обіймання яких зараховується до стажу роботи в галузі права, однак деякі з посад описані нечітко, що також може бути підставою для суб'єктивного підходу у визначенні стажу роботи як стажу в галузі права. Так, відповідно до пункту 3 зазначеного переліку до стажу роботи в галузі права слід зараховувати роботу на посадах юриста, юрисконсульта, головного юрисконсульта, начальника юридичного відділу, якщо такі посади за кваліфікаційними вимогами потребують наявності виключно повної вищої юридичної освіти за спеціальностями «081 Право» і «293 Міжнародне право» [10]. Досить часто у приватному секторі роботодавці не складають посадових інструкцій, де б містилися кваліфікаційні вимоги. У такому випадку єдиним способом з'ясувати кваліфікаційні вимоги посади є звернення до Довідника кваліфікаційних характеристик професій працівників (ДКХП). Втім, положення ДКХП мають рекомендаційний характер, і працівник може бути прийнятий на посаду навіть у разі невідповідності заявленим вимогам, наприклад, без відповідної освіти. Непоодинокими є випадки, коли юристами 
та юрисконсультами працюють студенти денної та заочної форм навчання. Припустимо, що особу з дипломом бакалавра було прийнято на посаду, що вимагає освіти за освітньо-кваліфікаційним рівнем магістра. Працівник на заочній формі навчання здобув рівень магістра і продовжує працювати на тій же посаді. Чи можна вважати зазначену посаду такою, що потребує наявності виключно повної юридичної освіти, якщо працівник належним чином виконував посадові обов’язки з дипломом бакалавра? Чи зараховуватиметься як стаж роботи у галузі права робота на такій посаді після здобуття рівня магістра? Правова невизначеність породжує досить багато дискусійних запитань.

Суб'єктивний фактор також має вагомий вплив у процесі проведення кваліфікаційного іспиту кандидатів. 3 цього приводу О. О. Первомайський слушно зазначив: $\ll$ Мене - звичайної людини, правника та судді Конституційного Суду - $є$ прохання до ініціаторів та так званих „драйверів“ цієї реформи: ставтесь до прокурорів та кандидатів на посади прокурорів гідно та 3 повагою під час проведення тестувань і співбесід, оскільки є великі сумніви у тому, що призначений на посаду прокурор, який відчув стосовно себе під час такого реформування неповагу та тотальну недовіру, буде ставитись 3 повагою до осіб, про яких він за історичною сутністю своєї посади має піклуватись»[1]. Тому з метою мінімізації негативного впливу суб'єктивного фактору на процедуру зайняття посади прокурора, необхідно чітко визначити межі дискреційних повноважень осіб, що беруть участь у доборі кандидатів.

Також у контексті основних напрямів реформи необхідно згадати про зміни у фінансуванні органів прокуратури. Пунктом 26 Прикінцевих положень Бюджетного кодексу було передбачено, що норми і положення статті 81 Закону (стосовно розмірів заробітних плат прокурорів) застосовуються у порядку та розмірах, встановлених Кабінетом Міністрів України, виходячи 3 наявних фінансових ресурсів державного і місцевого бюджетів та бюджетів фондів загальнообов'язкового державного соціального страхування.

Таким чином, певною мірою прокурори потрапляють у залежність від Кабінету Міністрів України, оскільки в уряду наявні дискреційні повноваження на визначення розмірів заробітної плати прокурорів.

Рішенням Конституційного Суду України від 26.03.2020 № 6p/2020 у справі № 1-223/2018(2840/18) вказані положення були визнані неконституційними. Основними причинами неконституційності даної норми було зазначено те, що належне фінансування інституту прокуратури $€$ «однією 3 необхідних передумов незалежної діяльності прокуратури, неупередженого, об'єктивного, безстороннього виконання прокурорами своїх функцій», а заробітна плата прокурорів є елементом організації та порядку діяльності прокуратури, а отже, ця заробітна плата відповідно до положень частини 2 статті 131-1 Конституції має визначатися виключно законом.

Щодо рішення є окрема думка судді О. О. Первомайського. Особливість даної окремої думки полягає в тому, що суддя погоджується 3 визнанням норми неконституційною, але водночас різко критикує мотивувальну частину рішення.

Так, суддя зазначає, що визнання заробітної плати прокурорів елементом організації та порядку діяльності прокуратури, є розширеним тлумаченням положень Конституції та профільного закону щодо організації та порядку діяльності, а рівень заробітної плати тих чи інших державних службовців, організація та порядок діяльності яких врегульовано законом, не обов'язково повинен регулюватися тим же законом. Якщо законодавець вважає за необхідне передбачити можливість регулювання розмірів заробітних плат виключно законом, то він прямо це передбачає, як було передбачено щодо заробітних плат суддів та суддів Конституційного Суду [1].

Якщо вважати включення заробітної плати до організації і порядку діяльності правильним, то це, у свою чергу, має стосуватися і нотаріату, органів досудового розслідування, органів і установ виконання покарань, тобто заробітні плати їхніх працівників також мають встановлюватися законами. Такий підхід призведе до перевантаження законодавчої бази і низької можливості пристосовувати нормативні положення до умов сьогодення. Суддя не бачить нічого негативного i, що найголовніше, неконституційного у закріпленні розміру заробітної плати деяких державних службовців у підзаконних нормативно-правових актах [1].

Таким чином, у цілому приймаючи правильне рішення, Конституційний Суд припустився неточностей у його мотивуванні, які мають бути витлумачені у подальших рішеннях.

\section{Висновки}

На сучасному етапі процес реформування прокуратури має позитивні моменти, як-то уточнення вимог до кандидатів на 
посаду прокурора та виключення ризиків для незалежності прокуратури. 3 іншого боку, реформа не охоплює визначення і конкретизацію мети, завдань та функцій прокуратури, не прибирає неузгодженості щодо понять вищої юридичної освіти та стажу роботи у галузі права, а дискусійні норми щодо заробітної плати прокурорів були визнані неконституційними 3 використанням хибної позиції в мотивуванні. Реформа прокуратури повинна мати системний характер, інакше нововведення і надалі характеризуватимуться непослідовністю.

\section{Список використаних джерел:}

1. Окрема думка судді Конституційного Суду України Первомайського О.О. у справі № $1-223 / 2018(2840 / 18)$ за конституційним поданням 50 народних депутатів України щодо відповідності Конституції України (конституційності) окремого положення пункту 26 розділу VI „Прикінцеві та перехідні положення“ Бюджетного кодексу України.

2. Великий тлумачний словник сучасної української мови (з дод. і допов.) / уклад. і голов. ред. В. Т. Бусел. Київ; Ірпінь: ВТФ «Перун», 2005. $1728 \mathrm{c}$

3. Лапкін А. В. Щодо визначення мети, завдань та функцій прокуратури. Правові горизонти. 2019. Вип. 17 (30). С. 97-101.

4. Про прокуратуру: Закон України від 14.10.2014 р. Відомості Верховної Ради України. 2015. № 2-3.

Taisiia Bodnaruk, Andrii Lapkin. The main directions of reforming the institution of the prosecutor's office at the present stage

The article exploresthe main directions of the prosecutor's office reforming at the presentstage, since the adoption of the updated Law of Ukraine "On the Prosecutor's Office", constitutional reform onjustice and significant changes to the abovementioned law in 2019. Emphasis is placed on the inconsistency and heterogeneity of the reform, which gives some scholars and lawyers reason to argue that one reform of the prosecutor's office is being carried out at the same time, and the next one is being started, without completing the previous one.

It is determined that during the years of independence of Ukraine the purpose, tasks and functions of the prosecutor's office have not been properly defined. The goal is toovague, the tasks are not fixed at the legislative level, and the functions are reflected in different ways in the Constitution of Ukraine and relevant legislation.

In addition, the prosecutor's office is overloaded with an excessive number of functions, which negatively affects the efficiency of its work.

There are also difficulties in carrying out the procedure of selecting candidates for the position of prosecutors, as the concept of higher legal education and work experience in the field of law is neither defined in details nor normatively enshrined. The question arises as to the possibility of recognizing a position that meets the requirements of experience in the field of law after obtaining a specialist or master's degree, if the person performed a job function in the specified position before receiving such a diploma. This uncertainty leads to the influence of a subjective factor in the selection of candidates.

There were positive changes in the legislation on the financing of the prosecutor's office, namely the abolition of restrictions on the salaries of prosecutors in accordance with the state and local budgets, which eliminated the risk of dependence of the prosecutor's office on the discretion of the Cabinet of Ministers. It is also noted that such a cancellation was made with the assumption of inaccuracies in the motivation, which may lead in the future to the obligation to provide the salaries of notaries, pre-trial investigation bodies, penitentiary bodies and penitentiary institutions only in legislation. Conclusions are made on the completeness and consistent implementation of the prosecutor's of fice reform at the present stage.

Key words: reforming of the prosecutor's office, the purpose of the prosecutor's office, the tasks of the prosecutor's office, the functions of the prosecutor's office, the financing of the prosecutor's office. 